\title{
The Effects of Chronic Norepinephrine Transporter Inactivation on Seizure Susceptibility in Mice
}

\author{
Todd H Ahern', Martin A Javors' ${ }^{2}$, Douglas A Eagles ${ }^{3}$, Jared Martillotti ${ }^{3}$, Heather A Mitchell', Larry Cameron \\ Liles' and David Weinshenker*,' \\ 'Department of Human Genetics, Emory University School of Medicine, Atlanta, GA, USA; '2Department of Psychiatry, University of Texas, \\ San Antonio, TX, USA; ${ }^{3}$ Department of Biology, Georgetown University, Washington, DC, USA
}

\begin{abstract}
Epilepsy and depression are comorbid disorders, but the mechanisms underlying their relationship have not been identified. Traditionally, many antidepressants have been thought to increase seizure incidence, although this remains controversial, and it is unclear which medications should be used to treat individuals suffering from both epilepsy and depression. Since the neurotransmitter norepinephrine (NE) has both antidepressant and anticonvulsant properties, we speculated that NE transporter (NET) inhibitor antidepressants might be therapeutic candidates for comorbid individuals. To test this idea, we assessed the effects of chronic administration (via osmotic minipump) of the selective NET inhibitor reboxetine on flurothyl-induced seizures in mice. We found that reboxetine had both proconvulsant and anticonvulsant properties; it lowered both seizure threshold and maximal seizure severity. NET knockout (NET KO) mice essentially phenocopied the effects of reboxetine on flurothyl-induced seizures, and the trends were extended to pentylenetetrazole and maximal electroshock seizures (MES). Furthermore, reboxetine had no further effect in NET KO mice, demonstrating the specificity of reboxetine for the NET. We next tested the chronic and acute effects of other classes of antidepressants (desipramine, imipramine, sertraline, bupropion, and venlafaxine) on seizure susceptibility. Only venlafaxine was devoid of proconvulsant activity, and retained some anticonvulsant activity. These results suggest that chronic antidepressant drug treatment has both proconvulsant and anticonvulsant effects, and that venlafaxine is a good candidate for the treatment of epilepsy and depression comorbidity.
\end{abstract}

Neuropsychopharmacology (2006) 31, 730-738. doi: I 0.1038/sj.npp. I 300847; published online 27 July 2005

Keywords: norepinephrine; antidepressant; norepinephrine transporter; epilepsy; seizure

\section{INTRODUCTION}

Epilepsy and depression are comorbid diseases; depressive disorders are the most common type of psychiatric comorbidity in patients with epilepsy, and patients with major depression have a higher frequency of epilepsy than the general population (Kanner and Nieto, 1999; Harden, 2002; Kanner and Balabanov, 2002; Barry, 2003). The mechanisms underlying this relationship, however, are unknown. Although there is some debate about the magnitude of the risk factors for comorbidity because of variance in study design and diagnostic criteria, most estimates place the risk for epileptics developing depression and for depressed patients developing epilepsy at four- to five-fold higher than the general population (Harden, 2002;

\footnotetext{
*Correspondence: Dr D Weinshenker, Department of Human Genetics, Emory University School of Medicine, Whitehead 301, 615 Michael St, Atlanta, GA 30322, USA, Tel: + I 404727 3106, Fax: + I 404727 3949, E-mail: dweinshenker@genetics.emory.edu

Received 6 May 2005; revised 16 June 2005; accepted 17 June 2005 Online publication: 22 June 2005 at http://www.acnp.org/citations/ Npp062205050303/default.pdf
}

Kanner and Balabanov, 2002). Treating comorbid individuals can be problematic; some anticonvulsants exacerbate depressive symptoms (Brent et al, 1987; Wiegartz et al, 1999; Kanner and Balabanov, 2002), and some antidepressants (eg bupropion, clomipramine) are reported to increase seizure susceptibility. Many of the newer antidepressants (eg sertraline, venlafaxine) appear safer but have not been systematically tested (Kanner et al, 2000; Kanner and Balabanov, 2002; Lee et al, 2003).

The neurotransmitter norepinephrine (NE) has both antidepressant and anticonvulsant properties. Multiple lines of evidence have accumulated over the years to suggest that depression is associated with changes in the noradrenergic system, while pharmacologically increasing NE potently alleviates depression (Ressler and Nemeroff, 1999; Frazer, 2000; Brunello et al, 2002). Likewise, endogenous NE is a critical inhibitor of seizure activity; stimulation of $\mathrm{NE}$ signaling powerfully inhibits seizures, whereas depletion of NE increases seizure susceptibility and accelerates epileptogenesis in nearly every animal model tested (Weinshenker and Szot, 2002; Giorgi et al, 2004). Furthermore, the anticonvulsant effects of multiple therapies for epilepsy 
are attenuated in rodents with NE deficiencies (Szot et al, 2001; Weinshenker and Szot, 2002; Schank et al, 2005), demonstrating that an intact NE system is important for the anticonvulsant activity of some epilepsy therapies.

Since NE is both antidepressant and anticonvulsant (Jobe et al, 1999), we speculated that NET inhibitors, which increase extracellular NE, might be ideal candidates for the treatment of individuals suffering from both epilepsy and depression. Acute administration of NET inhibitors is typically anticonvulsant (McIntyre et al, 1982; Clifford et al, 1985; Yan et al, 1993, 1998), while proconvulsant effects have been observed in a few studies where drug was administered chronically (McIntyre et al, 1982; Peterson et al, 1985; Escorihuela et al, 1989; Arai et al, 2003). There are, however, two caveats associated with these studies. First, most of them used desipramine (DMI) as the NET inhibitor. While DMI is a potent NET inhibitor and has good selectivity for NET over other monoamine transporters, it antagonizes other proteins, including receptors for histamine, acetylcholine, and adrenergic transmitters (Frazer, 1997). In particular, DMI blocks $\alpha_{1}$-adrenoreceptors, and blockade of these receptors is typically proconvulsant (Weinshenker et al, 2001; Weinshenker and Szot, 2002). Second, the studies using chronic administration typically gave once daily bolus injections of drug. While this treatment regimen may mimic human administration (ie one pill per day), it likely produces a transient exposure instead of the chronically high serum levels seen therapeutically in patients because the half-lives of these drugs are much shorter in rodents than they are in humans (eg Lemberger et al, 1985; Caccia et al, 1990). Furthermore, some of the molecular changes in the brain that are thought to underlie the efficacy of antidepressant drugs only occur in rodents using paradigms that mimic chronic drug serum levels, such as osmotic minipump administration (Benmansour et al, 1999; Weinshenker et al, 2002).

The experiments presented here were designed to systematically test the effects of chronic and acute NET inhibitor administration on seizure susceptibility. To address issues related to drug specificity, we used the selective NET inhibitor reboxetine, which does not interact with other transporters or receptors (Wong et al, 2000), and NET knockout (NET KO) mice, which have a specific deletion of the gene encoding NET. To mimic human antidepressant administration as closely as possible, we administered reboxetine via osmotic minipump for 3 weeks at a dose that produced therapeutic serum levels of drug. Finally, we systematically tested the chronic and acute effects of antidepressants from five other classes on seizure susceptibility (DMI, tricyclic NET inhibitor; imipramine, tricyclic NET and serotonin transporter (SERT) inhibitor, sertraline, selective SERT inhibitor, venlafaxine, selective NET and SERT inhibitor, and bupropion, selective NET and dopamine transporter (DAT) inhibitor).

\section{MATERIALS AND METHODS}

\section{Animals}

NET KO and wild-type (WT) control mice, maintained on a pure C57BL6/J background, were generated from NET + Iheterozygote breeders obtained from Mark Caron (Duke
University). NET $+/-$ mice were crossed, producing NET $+I+(\mathrm{WT})$ and NET $-I-$ (KO) mice. WT and KO mice were then bred separately to produce the mice used, and all NET WT mice were age-matched to NET KO mice in the initial reboxetine experiments. For the second set of experiments that compared the effects of different antidepressant drugs, mice of a mixed C57BL/6J and 129SvEv background were used. These mice were heterozygote $(D b h$ $+/-)$ controls from our dopamine $\beta$-hydroxylase knockout $(D b h-/-)$ colony. We originally used these mice because we wished to include the analysis of some $D b h-/-$ mice that completely lack NE (Thomas et al, 1995, 1998). However, the $D b h-/-$ mice did not tolerate the minipump surgeries well and showed signs of general malaise, and were not included in the final analysis. $D b h+/-$ mice have normal NE levels and were indistinguishable from WT littermates for all previously tested phenotypes, including flurothyl seizure susceptibility (Thomas et al, 1995, 1998; Thomas and Palmiter, 1997, Szot et al, 1999). The basal and reboxetine-induced seizure phenotypes of $D b h+/-$ mice were also similar to those observed for the NET WT mice. Thus, these mice were phenotypically WT. Adult male and female mice (3-7 months old at time of seizure testing) were used in all experiments, and control and experimental groups were age matched. No sex or age differences were observed and results were combined. Throughout the course of the experiment the colony room was maintained at $22^{\circ} \mathrm{C}$ with lights on from 0700 to 1900 . Food and water were available ad libitum, and animals were maintained according to guidelines outlined in the NIH Guide for Care and Use of Laboratory Animals. All experiments were approved by the Emory University and Georgetown University Institutional Animal Care and Use Committees.

\section{Drugs}

Antidepressant drugs used in this study were: reboxetine (Pfizer, Groton, CT), DMI (Sigma-Aldrich, St Louis, MO), imipramine (Sigma-Aldrich), sertraline (Pfizer), bupropion (Sigma-Aldrich), and venlafaxine (Wyeth, Monmouth Junction, MJ).

\section{Antidepressant Drug Administration}

For the chronic studies, drug was administered via Alzet ${ }^{\circledR}$ osmotic minipumps (Model \#2004, $0.25 \mu \mathrm{l} / \mathrm{h}, 28 \mathrm{~d}$; Durect, Cupertino, CA). Antidepressant drugs were dissolved in either $0.9 \% \mathrm{NaCl}$ (reboxetine, imipramine, venlafaxine, bupropion) or an aqueous solution containing 50\% ethanol and $0.9 \% \mathrm{NaCl}$ (DMI, sertraline), and loaded into pumps. Minipumps containing $0.9 \% \mathrm{NaCl}$ or an aqueous solution containing $50 \%$ ethanol and $0.9 \% \mathrm{NaCl}$ were used as vehicle controls. All pumps were placed in a sterile $37^{\circ} \mathrm{C}$ saline bath for 2 days before implantation. Mice were anesthetized with isoflurane and minipumps were implanted in the intraperitoneal cavity. All mice were given buprenorphine $(2.5 \mathrm{mg} / \mathrm{kg}$, s.c.) immediately following surgery. Flurothyl seizure susceptibility was tested 21 days following minipump implantation. For the acute studies, drug was administered i.p. $30 \mathrm{~min}$ prior to seizure testing. 


\section{Seizure Testing}

Flurothyl. Flurothyl seizure thresholds were determined as described previously (Szot et al, 1999). Mice were placed in an air-tight, clear Plexiglas ${ }^{\mathbb{R}}$ chamber, and the volatile convulsant flurothyl (2,2,2-trifluroethylether; Sigma-Aldrich) was infused via syringe pump at a rate of $20 \mu \mathrm{l} / \mathrm{min}$ onto filter paper from which it vaporized. The latency in seconds to the first myoclonic jerk (MJ) and clonic-tonic seizure (CT) was measured. MJ, the first behavioral sign of seizure, is evidenced as a brief, large-scale muscle twitch, and is commonly thought of as an index of seizure induction. CT, which appears later as repetitive, full-body convulsions with loss of posture, can be thought of as an index of seizure generalization. Also recorded was the number of mice progressing to tonic extension of the hindlimbs and death. Each mouse was tested individually, removed immediately from the chamber after completion of seizure behavior, and received only one exposure to flurothyl.

Pentylenetetrazole (PTZ). PTZ (Sigma-Aldrich) seizure induction was performed as previously described (Szot et al, 1999). PTZ was administered to NET KO and WT mice at a dose of $40 \mathrm{mg} / \mathrm{kg}$, i.p. All mice were placed in a clear Plexiglas ${ }^{\circledR}$ chamber and closely monitored for $10 \mathrm{~min}$. This observation time was chosen because mice that displayed seizure activity did so within the first few minutes after PTZ administration. Latency to the first MJ and CT seizure was recorded.

Maximal electroshock (MES). Shocks, each $0.9 \mathrm{~ms}$ in duration, were delivered via ear-clip electrodes at a frequency of 299 pulses/s for $100 \mathrm{~ms}$ at $20 \mathrm{~mA}$ using a constant-current device (Ugo Basile ECT Unit 7801, Varese, Italy). Seizure severity was determined by measuring the duration of tonic hindlimb extension, flexion, and the extension/flexion (E/F) ratio. Flexion duration was timed from the instant the shock was delivered until the hindlimbs went through an angle of $90^{\circ}$ to the plane of the body and extension was timed from that point until the hindlimbs relaxed. As the end of extension was variable, abrupt palpable relaxation of the body was taken as the end of the extension phase.

\section{Analysis of Serum Drug Levels}

Trunk blood was collected in Microtainer serum tubes (Fisher Scientific, Pittsburgh, PA) from mice either immediately following seizure (in the cases where the seizure was lethal) or 1-3 h following seizure (in the cases where seizure was not fatal). Tubes were spun for $5 \mathrm{~min}$ at $10 \mathrm{~K}$, and serum was placed in a sterile tube and stored at $-80^{\circ} \mathrm{C}$ until analysis.

Serum concentrations of sertraline, DMI, reboxetine, venlafaxine, imipramine, and bupropion were determined using HPLC with UV detection $(214 \mathrm{~nm})$. After addition of $\mathrm{NaOH}$ to buproprion, DMI, imipramine, sertraline, and reboxetine samples, these drugs were extracted into a mixture of $5 \%$ isopropanol/95\% hexane, then back-extracted into $12 \mathrm{mM}$ phosphate buffer ( $\mathrm{pH} 2.5)$. Venlafaxine samples were treated with saturated sodium borate solution, extracted into ethyl ether, and then back-extracted into
Table I Serum Concentrations of Antidepressants

\begin{tabular}{lccc}
\hline & \multicolumn{3}{c}{ Serum level } \\
\cline { 2 - 4 } Drug & $\begin{array}{c}\text { Dose } \\
(\mathbf{m g} / \mathbf{k g} / \text { day })\end{array}$ & $\begin{array}{c}\text { Steady state } \\
\mathbf{( n g / m l )}\end{array}$ & $\begin{array}{c}\text { Therapeutic } \\
\mathbf{( n g / m l})\end{array}$ \\
\hline Reboxetine $(n=19)$ & 20 & $335 \pm 65$ & $100-400$ \\
Desipramine $(n=14)$ & 20 & $275 \pm 49$ & $125-600$ \\
Imipramine $(n=9)$ & 120 & $312 \pm 38$ & $200-300$ \\
Sertraline $(n=13)$ & 40 & $8 \pm 5$ & $30-150$ \\
Bupropion $(n=13)$ & 40 & $76 \pm 17$ & $50-100$ \\
Venlafaxine $(n=11)$ & 20 & $122 \pm 26$ & $100-400$ \\
Venlafaxine $(n=8)$ & 40 & $500 \pm 96$ & $100-400$ \\
\hline Serum concen & 40 &
\end{tabular}

Serum concentrations (mean \pm SEM) of antidepressants were after 21 days of treatments by osmotic minipump. As a reference, the human therapeutic drug level guidelines are also listed (Baldessarini, 1989; Kaye et al, 1989; Charlier et al, 2000)

$10 \mathrm{mM} \mathrm{HCl}(\mathrm{pH} 2.0)$. Extracted samples of DMI, imipramine, sertraline, and reboxetine were analyzed using a Waters Spherisorb CN column $(5 \mu \mathrm{m}, 4.6 \mathrm{~mm} \times 250 \mathrm{~mm})$ and a mobile phase containing $70 \%$ acetonitrile, $13 \%$ methanol, and $17 \%$ of $10 \mathrm{mM}$ phosphate buffer ( $\mathrm{pH} 6.7$ ). Extracted samples of venlafaxine and bupropion were analyzed using an Alltech Alltima C18 column $(5 \mu \mathrm{m}$, $4.6 \mathrm{~mm} \times 150 \mathrm{~mm}$ ) and a mobile phase containing $15 \%$ acetonitrile and $85 \%$ of $100 \mathrm{mM}$ phosphate buffer (pH 2.5). Internal standards were used for all analyses except venlafaxine. All reagents were HPLC grade. Serum concentrations were expressed in $\mathrm{ng} / \mathrm{ml}$.

After pilot experiments to determine optimal doses, we achieved serum levels that fell within or very close to human therapeutic range for each drug, with the exception of sertraline (Table 1). Even at the solubility limit of sertraline (a concentration that delivered $40 \mathrm{mg} / \mathrm{kg} /$ day), the mean sertraline level was far below human therapeutic levels and was undetectable in some mice.

\section{Statistics}

For analyses of seizure threshold and duration, $T$-tests were used to compare two groups, and one-way ANOVA followed by Dunnett's posthoc test was used when comparing multiple groups to vehicle. For number of mice progressing to tonic extension and death, treatment groups were compared to controls using Fisher's Exact Test. A Pvalue of $<0.05$ was considered significant. Graphpad Instat and Prism for Macintosh were used for all statistical analysis.

\section{RESULTS}

\section{Chronic Reboxetine Administration has Both Proconvulsant and Anticonvulsant Effects}

Most previous studies have examined the effects of acute antidepressant administration on seizure susceptibility, and the few that have used chronic administration employed drugs that have targets other than the NET (eg DMI) and 
paradigms that did not support therapeutic serum levels (eg daily i.p. injection). To circumvent these caveats, we used a NET inhibitor that has no other known targets (reboxetine) and a paradigm that mimics therapeutic serum levels (chronic infusion via osmotic minipump; Table 1). Chronic administration of reboxetine to WT mice significantly lowered seizure threshold (shorter latency to first MJ and generalized CT seizure; Figure 1a), but also tended to reduce maximal seizure severity, although the effect was not quite significant (4/9 vehicle-treated mice died, while 0/9 reboxetine-treated mice died; $P=0.08$ by Fisher's Exact Test; Table 2).

We speculated that if the effects of reboxetine on seizures were exclusively mediated by chronic NET blockade, then the seizure phenotype of mice completely lacking NET (NET KO mice) would be similar to reboxetine-treated WT
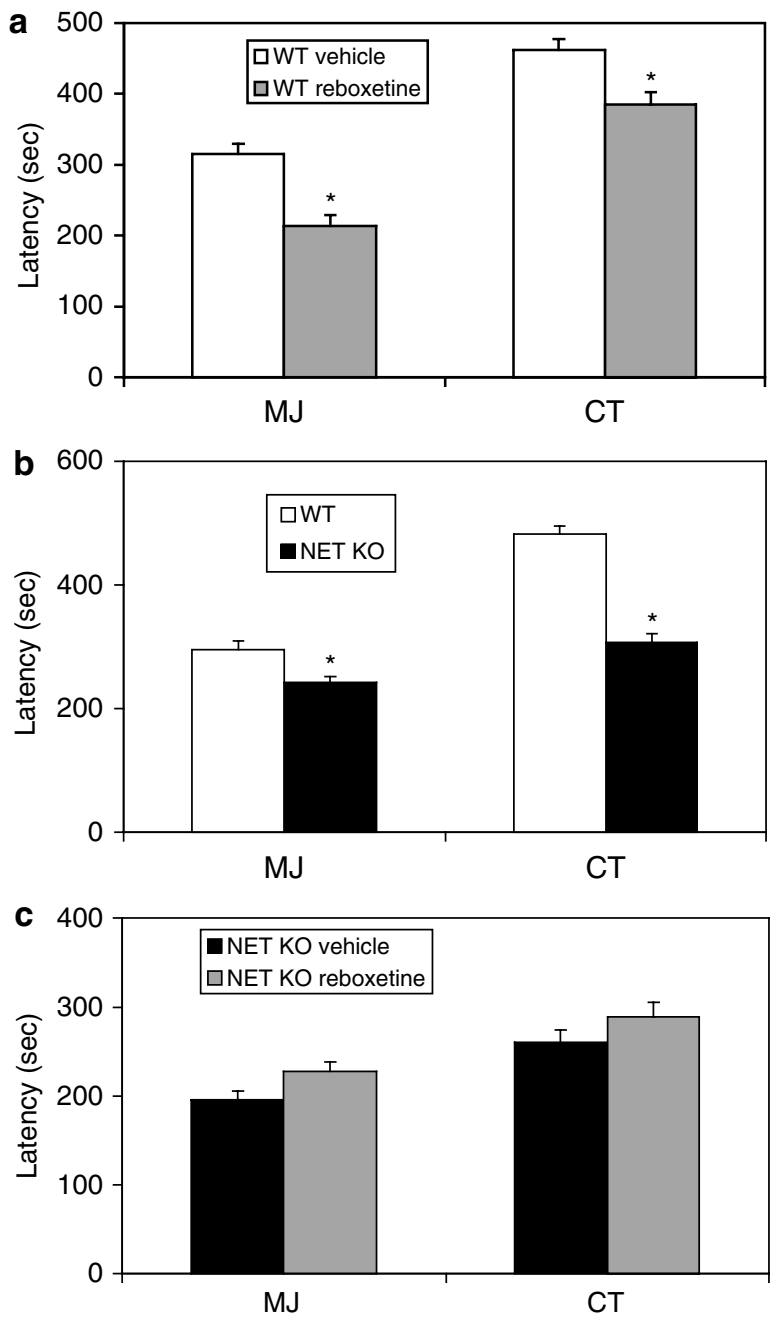

Figure I Effects of chronic reboxetine administration and NET genotype on flurothyl-induced seizure susceptibility. Shown is mean \pm SEM latency to first myoclonic jerk (MJ) and clonic-tonic seizure (CT) after flurothyl administration in (a) wild-type (WT) mice administered vehicle $(0.9 \% \mathrm{NaCl})$ or reboxetine $(20 \mathrm{mg} / \mathrm{kg} / \mathrm{d})$ via osmotic minipump for $2 \mathrm{l} \mathrm{d}$ ( $n=9$ per group; $* P<0.0$ I compared to $W T$ vehicle), (b) untreated WT and NET knockout (NET KO) mice ( $n=16$ per group; $* P<0.01$ compared to $\mathrm{WT}$ ), and (c) NET KO mice administered vehicle $(0.9 \% \mathrm{NaCl})$ or reboxetine $(20 \mathrm{mg} / \mathrm{kg} /$ day $)$ via osmotic minipump for 21 days $(n=5-6$ per group). mice. Furthermore, reboxetine should have no further effect on NET KO mice. We found that, similar to WT mice treated chronically with reboxetine, NET KO mice had increased seizure susceptibility (significantly shorter latency to $\mathrm{MJ}$ and CT; Figure $1 \mathrm{~b}$ ) and decreased maximal seizure severity (fewer NET KO mice progressed to tonic extension and death; Table 2). In contrast to its effects on WT mice, reboxetine did not alter seizures in NET KO mice (Figure 1c; Table 2). These results suggest that the effects of reboxetine on flurothyl-induced seizures are mediated solely by NET blockade.

We next addressed whether the effects of chronic NET inactivation on seizure phenotypes extended to other methods of seizure induction. We used PTZ seizure susceptibility as an alternate measure of seizure threshold and MES as an alternate measure of maximal seizure severity. Both the PTZ seizure threshold phenotype and the MES maximal seizure severity phenotypes of NET KO mice were similar to that observed with flurothyl; NET KO mice had a shorter latency to MJ and CT for PTZ seizures (Figure 2) and had a shorter duration of tonic extension for MES seizures (Figure 3). These results confirm that chronic

Table 2 Effects of NET Genotype and Reboxetine on Maximal Seizure Severity

\begin{tabular}{llcc}
\hline Genotype & Treatment & $\begin{array}{c}\text { Tonic extension } \\
\text { (over total) }\end{array}$ & $\begin{array}{c}\text { Death } \\
\text { (over total) }\end{array}$ \\
\hline WT & None & $14 / 16$ & $4 / 16$ \\
NET KO & None & $3 / 16^{*}$ & $0 / 16$ \\
WT & Vehicle & $7 / 9$ & $4 / 9$ \\
WT & Reboxetine & $7 / 9$ & $0 / 9$ \\
NET KO & Vehicle & $0 / 5^{\#}$ & $0 / 5$ \\
NET KO & Reboxetine & $0 / 6^{\#}$ & $0 / 6$ \\
\hline
\end{tabular}

NET KO and WT control mice were either untreated for administered vehicle or reboxetine $(20 \mathrm{mg} / \mathrm{kg} / \mathrm{day})$ via osmotic minipump for 21 days prior to seizure induction with flurothyl. Shown is the number of mice that displayed tonic extension and death following generalized seizure over the total number of mice tested for each genotype and treatment group. Data were analyzed by Fisher's Exact Test. ${ }^{*} P<0.01$ compared to WT. ${ }^{\#} P<0.05$ compared to WT vehicle.

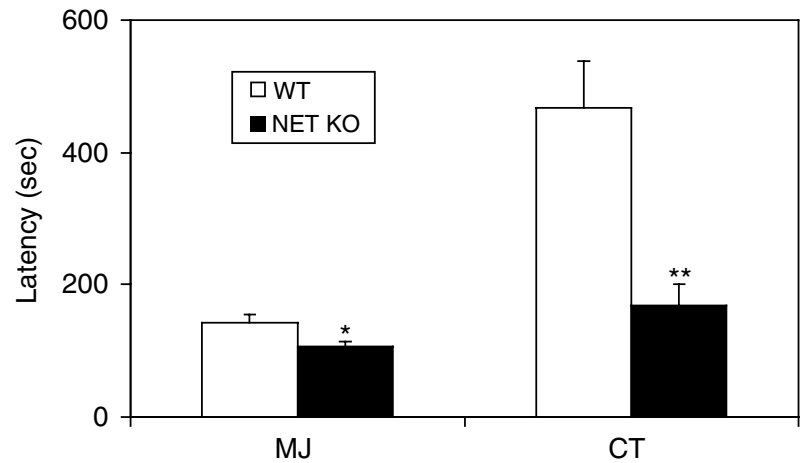

Figure 2 Effects of NET genotype on pentylenetetrazole-induced seizure susceptibility. Shown is mean \pm SEM latency to first myoclonic jerk (MJ) and clonic-tonic seizure (CT) in wild-type (WT) and NET knockout (NET KO) mice after administration of pentylenetetrazole (PTZ; $40 \mathrm{mg} / \mathrm{kg}$, i.p.; $n=10$ per group; $* P<0.05$, ** $P<0.01$ compared to WT). 


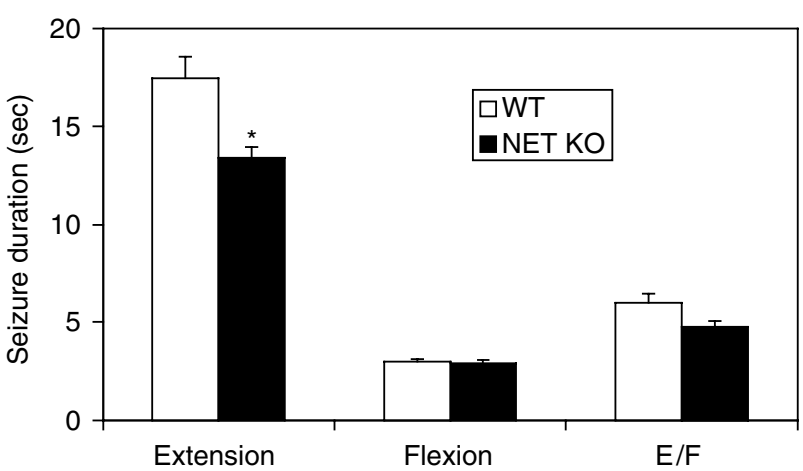

Figure 3 Effects of NET genotype on maximal electroshock seizures. Shown is mean \pm SEM duration of tonic extension, flexion, and the tonic extension/flexion ratio in wild-type (WT) and NET knockout (NET KO) mice after seizure induction with maximal electroshock (MES; $n=13-18$ per group; ${ }^{*} P<0.0$ l compared to $\mathrm{WT}$ )

NET inactivation has both proconvulsant (lowering of seizure threshold) and anticonvulsant (reduction of maximal seizure severity) properties.

\section{Effects of Chronic Antidepressant Drug Treatment on Seizure Susceptibility}

Our results suggest that, contrary to our hypothesis, reboxetine is not a good candidate to treat comorbid depression and epilepsy due to its proconvulsant effects. To determine whether a different type of antidepressant would be a better therapeutic candidate, we tested the effects of chronic treatment with a tricyclic NET inhibitor (DMI), a tricyclic NET and SERT inhibitor (imipramine), a selective SERT inhibitor (sertraline), a selective NET and DAT inhibitor (bupropion), and a selective NET and SERT inhibitor (venlafaxine) on flurothyl seizure susceptibility. We achieved therapeutic serum levels with all antidepressants tested except sertraline (Table 1). We found that, like reboxetine, DMI and imipramine lowered seizure threshold (significantly reduced latency to MJ, strong trend towards reducing latency to $\mathrm{CT}$ ), while sertraline, bupropion, and venlafaxine had no effect (Figure 4). As we observed previously, reboxetine had an anticonvulsant effect in terms of seizure severity (reduced number of mice progressing to death; Table 3). DMI also tended to reduce seizure severity, but the results did not quite reach significance $(P=0.07$ for both tonic extension and death by Fisher's Exact Test; Table 3).

Since the NET and SERT inhibitor imipramine had proconvulsant properties, we were intrigued by the lack of a proconvulsant effect for the NET and SERT inhibitor venlafaxine. Although venlafaxine serum levels were in therapeutic range, they were on the low end (Table 1). To determine whether a higher dose of venlafaxine would be proconvulsant, we doubled the venlafaxine dose from 20 to $40 \mathrm{mg} / \mathrm{kg} / \mathrm{day}$, which elevated serum drug levels from 122 to $500 \mathrm{ng} / \mathrm{ml}$, and retested seizure susceptibility. The higher dose of venlafaxine still did not significantly lower seizure thresholds (Figure 4), and in fact tended to decrease maximal seizure severity (fewer mice died; $P=0.09$ by Fisher's Exact Test; Table 3). These results suggest that the

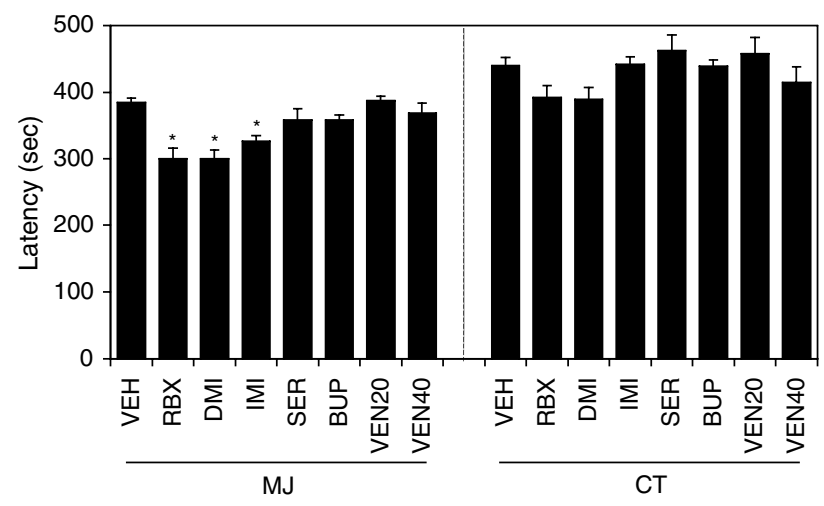

Figure 4 Effects of chronic antidepressant drug treatment on flurothylinduced seizure susceptibility. Shown is mean \pm SEM latency to first myoclonic jerk (MJ) and clonic-tonic seizure (CT) after flurothyl administration in mice administered vehicle $(0.9 \% \mathrm{NaCl}$ or $50 \% \mathrm{EtOH}$ in $0.9 \% \mathrm{NaCl}$ ), reboxetine (RBX; $20 \mathrm{mg} / \mathrm{kg} /$ day), desipramine (DMl; $20 \mathrm{mg} / \mathrm{kg} /$ day), imipramine (IMI; $120 \mathrm{mg} / \mathrm{kg} /$ day), sertraline (SER; $40 \mathrm{mg} / \mathrm{kg} /$ day), bupropion (BUP; $40 \mathrm{mg} / \mathrm{kg} /$ day), or venlafaxine (VEN20; $20 \mathrm{mg} / \mathrm{kg} / \mathrm{day}$, VEN40; $40 \mathrm{mg} / \mathrm{kg} /$ day) via osmotic minipump for $21 \mathrm{~d}(n=7-15$ per group; $* P<0.0$ l compared to vehicle)

Table 3 Effects of Chronic Antidepressant Treatment on Maximal Seizure Severity

\begin{tabular}{lccc}
\hline Drug & $\begin{array}{c}\text { Dose } \\
\text { (mg/kg/day) }\end{array}$ & $\begin{array}{c}\text { Tonic extension } \\
\text { (over total) }\end{array}$ & $\begin{array}{c}\text { Death } \\
\text { (over total) }\end{array}$ \\
\hline Vehicle & NA & $15 / 16$ & $12 / 16$ \\
Reboxetine & 20 & $10 / 10$ & $0 / 10^{*}$ \\
Desipramine & 20 & $4 / 7$ & $2 / 7$ \\
Imipramine & 120 & $5 / 7$ & $4 / 7$ \\
Sertraline & 40 & $4 / 7$ & $4 / 7$ \\
Bupropion & 40 & $9 / 12$ & $7 / 12$ \\
Venlafaxine & 20 & $7 / 9$ & $5 / 9$ \\
Venlafaxine & 40 & $6 / 8$ & $3 / 8$ \\
\hline
\end{tabular}

Antidepressants were administered via osmotic minipump for 21 days prior to seizure induction with flurothyl. Shown are the number of mice that displayed tonic extension and death following generalized seizure over the total number of mice tested for each drug. Data were analyzed by Fisher's Exact Test. *P $P<0.05$ compared to vehicle control.

effects of venlafaxine in the brain are fundamentally different in some way from imipramine.

\section{Effects of Acute Antidepressant Drug Treatment on Seizure Susceptibility}

In order to compare the effects of chronic and acute antidepressant treatment on seizure susceptibility, we administered each antidepressant (a single i.p. bolus of the chronic therapeutic daily dose) to seizure-naïve mice $30 \mathrm{~min}$ prior to induction of seizures with flurothyl. In contrast to the effects of chronic treatment, most of the antidepressants did not significantly affect seizure thresholds (Figure 5). The one exception was sertraline, which was profoundly proconvulsant. Reboxetine and the lower dose of venlafaxine reduced the number of mice that died, while 


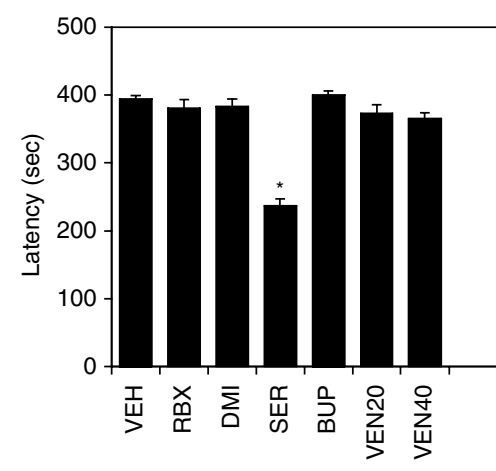

MJ

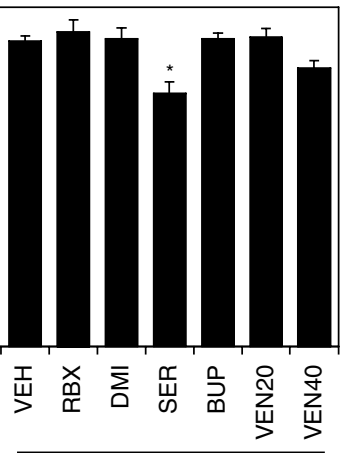

CT
Figure 5 Effects of acute antidepressant drug treatment on flurothylinduced seizure susceptibility. Shown is mean \pm SEM latency to first myoclonic jerk (MJ) and clonic-tonic seizure (CT) in mice administered vehicle $(0.9 \% \mathrm{NaCl})$, reboxetine $(\mathrm{RBX} ; 20 \mathrm{mg} / \mathrm{kg})$, desipramine (DMI; $20 \mathrm{mg} / \mathrm{kg}$ ), sertraline (SER; $40 \mathrm{mg} / \mathrm{kg}$ ), bupropion (BUP; $40 \mathrm{mg} / \mathrm{kg}$ ), or venlafaxine (VEN20; $20 \mathrm{mg} / \mathrm{kg}$, VEN40; $40 \mathrm{mg} / \mathrm{kg}$ ) via i.p. injection $30 \mathrm{~min}$ prior to seizure induction with flurothyl $(n=6-1$ I per group; $* P<0.05$ compared to vehicle).

the higher dose of venlafaxine suppressed both tonic extension and death (Table 4). Sertraline and bupropion also appeared to reduce maximal seizure severity, but that result is somewhat deceiving. Mice treated with vehicle or other antidepressants that did not progress to tonic extension typically had one short ( $\sim 10 \mathrm{~s})$ CT seizure, and then entered a prolonged postictal period with no obvious seizure activity. For this reason, mice are removed from the flurothyl chamber after $10 \mathrm{~min}$ (Szot et al, 1999) and thus the numbers listed in Table 4 are for the first $10 \mathrm{~min}$ after flurothyl administration. In contrast, after the first CT seizure, sertraline- or bupropion-treated mice entered a state of status epilepticus; they had repeated CT seizure activity that continued for up to $\sim 20 \mathrm{~min}$, at which time most of them went into tonic extension and died (data not shown).

\section{DISCUSSION}

\section{Chronic NET Inactivation has Both Proconvulsant and} Anticonvulsant Effects

Since NE is anticonvulsant in nearly all known seizure models (Weinshenker and Szot, 2002), we speculated that NET inhibitors, which increase extracellular NE, would suppress seizures. In support of this hypothesis, we found that the selective NET inhibitor reboxetine reduced maximal flurothyl seizure severity when administered both chronically and acutely. Flurothyl and MES seizures in NET KO mice were also less severe, and reboxetine had no further effect in NET KO mice. Thus, as predicted, selective genetic or pharmacological inactivation of NET had anticonvulsant properties.

Paradoxically, chronic NET inactivation was also proconvulsant, as both NET KO and reboxetine-treated WT mice had a reduction in seizure threshold. How can we reconcile the anticonvulsant effect of NE and the proconvulsant effect of NET blockade, which increases extracel-
Table 4 Effects of Acute Antidepressant Treatment on Maximal Seizure Severity

\begin{tabular}{lccc}
\hline Drug & $\begin{array}{c}\text { Dose } \\
(\mathbf{m g} / \mathbf{k g} / \text { day })\end{array}$ & $\begin{array}{c}\text { Tonic extension } \\
\text { (over total) }\end{array}$ & $\begin{array}{c}\text { Death } \\
\text { (over total) }\end{array}$ \\
\hline Vehicle & $\mathrm{NA}$ & $1 / / \mathrm{I}$ & $10 / \mathrm{I}$ \\
Reboxetine & 20 & $8 / 8$ & $3 / 8^{*}$ \\
Desipramine & 20 & $7 / 8$ & $7 / 8$ \\
Imipramine & 120 & $\mathrm{NA}$ & $\mathrm{NA}$ \\
Sertraline & 40 & $1 / 6^{*}, \mathrm{a}$ & $1 / 6^{*}, \mathrm{a}$ \\
Bupropion & 40 & $1 / 8^{*}, \mathrm{a}$ & $0 / 8^{*}, \mathrm{a}$ \\
Venlafaxine & 20 & $8 / 8$ & $3 / 8^{*}$ \\
Venlafaxine & 40 & $2 / 8^{*}$ & $1 / 8^{*}$ \\
\hline
\end{tabular}

Antidepressants were administered via i.p. injection 30 min prior to seizures induction with flurothyl. Shown are the number of mice that displayed tonic extension and death following generalized seizure over the total number of mice tested for each drug. Mice given imipramine were not tested for seizure susceptibility because they displayed ataxia and sedation following drug administration. Data were analyzed by Fisher's Exact Test. $* P<0.01$ compared to vehicle control.

aDenotes drugs that induced status epilepticus.

lular NE? One clue is that while both chronic and acute NET blockade elevate extracellular NE, acute blockade of NET lacked the proconvulsant effect on seizure threshold but retained the ability to suppress seizure severity. This result indicates that increasing $\mathrm{NE}$ is not proconvulsant per se, but rather suggests that chronic NET blockade activates compensatory mechanisms that are proconvulsant. It is well established that chronic but not acute NET inactivation results in many changes in the noradrenergic system, including a downregulation of tyrosine hydroxylase (the rate-limiting enzyme in NE synthesis; Nestler et al, 1990), burst firing of the locus coeruleus (LC, the major brain noradrenergic cell group; Grant and Weiss, 2001), the NET (Benmansour et al, 1999; Weinshenker et al, 2002), and adrenergic receptors (Bergstrom and Kellar, 1979; Xu et al, 2000; Invernizzi and Garattini, 2004). A decrease in LC activity after chronic NET blockade was associated with an increase in the activity of hippocampal neurons that received noradrenergic innervation (Huang et al, 1980), and hippocampal hyperexcitability often contributes to seizures. Finally, an increase in extracellular NE could enhance the activation of inhibitory $\alpha_{2}$-adrenergic autoreceptors. Thus, although basal extracellular NE levels are elevated, chronic NET blockade may result in an overall decrease in NE signaling under some conditions, which could produce a proconvulsant effect. Another intriguing possibility is the interaction between the noradrenergic and GABAergic systems. NE can enhance hippocampal GABA function, and some studies have shown that chronic antidepressant treatment downregulates not only adrenergic receptors but also $\mathrm{GABA}_{\mathrm{A}}$ receptors (Suzdak and Gianutsos, 1985; Dennis et al, 1994; Sanacora et al, 2000). A decrease in GABA function could contribute to the proconvulsant effects of antidepressants.

In the preceding two paragraphs, we have presented evidence that chronic NET blockade could have anticonvulsant and proconvulsant effects, but how can we 
explain both effects occurring essentially simultaneously? The proconvulsant effect of chronic NET inactivation is most evident for moderate clonic seizures (MJ), while the anticonvulsant effect is restricted to very severe seizures (tonic extension, death). One possibility is that different brain regions are involved. It is generally accepted that forelimb clonic seizures (eg MJ, rearing, and falling seizures) and hindlimb tonic seizures have partially overlapping but distinct anatomical substrates; clonic seizures predominantly activate forebrain regions, while tonic seizures also recruit brainstem structures (Browning, 1994; Eells et al, 2004). The effects of chronic NET blockade on NE signaling may differ between forebrain and brainstem regions. In support of this hypothesis, the decrease in $\beta_{1^{-}}$ adrenergic receptors observed after chronic DMI treatment was much more evident in the cortex compared to subcortical regions (Bergstrom and Kellar, 1979), and $\alpha_{2^{-}}$ adrenergic receptor desensitization after chronic reboxetine was observed in the hippocampus but not the LC (Parini et al, 2005). Our results suggest that the compensatory downregulation of NE signaling may preferentially occur in the forebrain. Another possibility is the involvement of noradrenergic cotransmitters. LC neurons coexpress anticonvulsant neuropeptides such as NPY and galanin. Since neuropeptides are typically released under conditions of very high neuronal excitability, NPY and galanin may be preferentially released from LC neurons to prevent severe brainstem seizures under our experimental conditions. In support of this idea, the activation of LC neurons is much greater during brainstem tonic seizures than during forebrain clonic seizures (Eells et al, 2004).

\section{Therapeutic Implications}

Although depression is the most common comorbid psychiatric disorder in epilepsy, it is still severely underdiagnosed and undertreated in the epileptic population (Wiegartz et al, 1999; Harden, 2002; Kanner and Balabanov, 2002). Since depression appears to have a much greater impact on the quality of life of epileptic individuals than seizure frequency or severity (Johnson et al, 2004; Boylan et al, 2004), finding safe and effective treatment is critical. Historically, this has been problematic because some antidepressants exacerbate seizures, especially when drug doses are high (Pisani et al, 1999). SSRIs are typically recommended for alleviating depressive symptoms in epileptics, and appear to be relatively safe (Kanner and Nieto, 1999; Kanner et al, 2000; Pisani et al, 2002; Isbister et al, 2004), although some preclinical studies have suggested otherwise (Raju et al, 1999; Zienowicz et al, 2005). We were unable to test the effects of chronic sertraline administration due to rapid metabolism and/or excretion that precluded the maintenance of human therapeutic serum levels in the mice, but a high dose administered acutely was proconvulsant.

We speculated that selective NE reuptake inhibitors might be good candidates for treating comorbid individuals because NE has both antidepressant and anticonvulsant properties. However, we found that the selective NET blocker reboxetine possessed proconvulsant properties when administered chronically, as did the tricyclic DMI, probably due to compensatory mechanisms activated by chronic administration. Therefore, NET inhibitor antidepressants may not be safe for use in seizure-prone individuals.

There have been few systematic, preclinical comparisons of different classes of antidepressant drugs on seizure susceptibility, and none to our knowledge has utilized chronic administration at therapeutic serum drug levels. We found that chronic administration reboxetine, DMI, and imipramine had proconvulsant effects. In addition, acute administration of bupropion or sertraline was proconvulsant, and a seizure risk has been documented clinically for bupropion (Richmond and Zwar, 2003). The only antidepressant in our study that was devoid of significant proconvulsant effects was the selective NET/SERT inhibitor venlafaxine, even when administered at a relatively high dose. Venlafaxine is of considerable interest because, unlike other NET inhibitors like reboxetine, DMI, and imipramine, it does not cause a downregulation in NET density in rats after chronic administration, and the lack of effect on the NET cannot be attributed to its dual reuptake-inhibiting properties (Gould et al, 2004). Venlafaxine may interact with the NET and the noradrenergic system in a novel way, and it is possible that venlafaxine's lack of proconvulsant activity is related to this difference. Like many antidepressants, venlafaxine overdose has occasionally been reported to cause seizures, but it appears to be safe at therapeutic doses (White et al, 1997; Pisani et al, 2002). Our results suggest that venlafaxine warrants further investigation as a treatment for depression in the epileptic population.

In general, most antidepressants appear to be proconvulsant under some conditions. Therefore, it may be wise to explore alternative treatments for depression in comorbid individuals (Barry, 2003). Vagus nerve stimulation and the ketogenic diet were originally developed to treat epilepsy, and both treatments also appear to have antidepressant properties (El-Mallakh and Paskitti, 2001; Krahl et al, 2004; Murphy et al, 2004; Schachter, 2004). Interestingly, an intact noradrenergic system is critical for the anticonvulsant effect of vagus nerve stimulation and the ketogenic diet (Krahl et al, 1998; Szot et al, 2001). Thus, despite the proconvulsant properties of chronic NET inhibition, increasing NE signaling may still represent an effective therapy for epilepsy and depression comorbidity.

\section{ACKNOWLEDGEMENTS}

We thank Marc Caron for providing NET KO breeding pairs, Pfizer for providing reboxetine and sertraline, Wyeth for providing venlafaxine, David Archer for use of anesthesia equipment, and Patti Szot for critical reading of the manuscript. This work was funded in part by the Epilepsy Foundation, the National Association for Research on Schizophrenia and Depression, and the Georgetown University Department of Biology.

\section{REFERENCES}

Arai S, Morita K, Kitayama S, Kumagai K, Kumagai M, Kihira K et al (2003). Chronic inhibition of the norepinephrine transporter in the brain participates in seizure sensitization to cocaine and local anesthetics. Brain Res 964: 83-90. 
Baldessarini RJ (1989). Current status of antidepressants: clinical pharmacology and therapy. J Clin Psychiatr 50: 117-126.

Barry JJ (2003). The recognition and management of mood disorders as a comorbidity of epilepsy. Epilepsia 44(Suppl 4): $30-40$.

Benmansour S, Cecchi M, Morilak DA, Gerhardt GA, Javors MA, Gould GG et al (1999). Effects of chronic antidepressant treatments on serotonin transporter function, density, and mRNA level. J Neurosci 19: 10494-10501.

Bergstrom DA, Kellar KJ (1979). Adrenergic and serotonergic receptor binding in rat brain after chronic desmethylimipramine treatment. J Pharmacol Exp Ther 209: 256-261.

Brent DA, Crumrine PK, Varma RR, Allan M, Allman C (1987). Phenobarbital treatment and major depressive disorder in children with epilepsy. Pediatrics 80: 909-917.

Boylan LS, Flint LA, Labovitz DL, Jackson SC, Starner K, Devinsky O (2004). Depression but not seizure frequency predicts quality of life in treatment-resistant epilepsy. Neurology 62: 258-261.

Browning RA (1994). Anatomy of generalized seizures. In: MalaFosse A, Genton P, Hirsch E, Marescaux C, Broglin D, Bernasconi R (eds). Idiopathic Generalized Epilepsies: Clinical, Experimental and Genetic Aspects. John Libbey and Company Ltd: London. pp 399-413.

Brunello N, Mendlewicz J, Kasper S, Leonard B, Montgomery S, Nelson J et al (2002). The role of noradrenaline and selective noradrenaline reuptake inhibition in depression. Eur Neuropsychopharmacol 12: 461-475.

Caccia S, Cappi M, Fracasso C, Garattini S (1990). Influence of dose and route of administration on the kinetics of fluoxetine and its metabolite norfluoxetine in the rat. Psychopharmacology (Berlin) 100: $509-514$

Charlier C, Pinto E, Ansseau M, Plomteux G (2000). Relationship between clinical effects, serum drug concentration, and concurrent drug interactions in depressed patients treated with citalopram, fluoxetine, clomipramine, paroxetine or venlafaxine. Hum Psychopharmacol 15: 453-459.

Clifford DB, Rutherford JL, Hicks FG, Zorumski CF (1985). Acute effects of antidepressants on hippocampal seizures. Ann Neurol 18: 692-697.

Dennis T, Beauchemin V, Lavoie N (1994). Antidepressantinduced modulation of GABAA receptors and beta-adrenoceptors but not GABAB receptors in the frontal cortex of olfactory bulbectomised rats. Eur J Pharmacol 262: 143-148.

Eells JB, Clough RW, Browning RA, Jobe PC (2004). Comparative fos immunoreactivity in the brain after forebrain, brainstem, or combined seizures induced by electroshock, pentylenetetrazol, focally induced and audiogenic seizures in rats. Neuroscience 123: 279-292.

El-Mallakh RS, Paskitti ME (2001). The ketogenic diet may have mood-stabilizing properties. Med Hypotheses 57: 724-726.

Escorihuela RM, Boix F, Corda MG, Tobena A, Fernandez Teruel A (1989). Chronic but not acute antidepressant treatment increases pentetrazol-induced convulsions in mice. J Pharm Pharmacol 41: 143-144.

Frazer A (1997). Pharmacology of antidepressants. J Clin Psychopharmacol 17(Suppl 1): 2S-18S.

Frazer A (2000). Norepinephrine involvement in antidepressant action. J Clin Psychiatr 61 (Suppl 10): 25-30.

Giorgi FS, Pizzanelli C, Biagioni F, Murri L, Fornai F (2004). The role of norepinephrine in epilepsy: from the bench to the bedside. Neurosci Biobehav Rev 28: 507-524.

Gould GG, Benmansour S, Frazer A (2004). Interactions between serotonergic and noradrenergic systems are not responsible for venlafaxine's lack of effect on serotonin (5-HT) and norepinephrine (NE) transporter density. Soc Neurosci Abstr 54: 9.

Grant MM, Weiss JM (2001). Effects of chronic antidepressant drug administration and electroconvulsive shock on locus coeruleus electrophysiologic activity. Biol Psychiatr 49: 117-129.
Harden CL (2002). The co-morbidity of depression and epilepsy: epidemiology, etiology, and treatment. Neurology 59(Suppl 4): S48-S55.

Huang YH, Maas JW, Hu GH (1980). The time course of noradrenergic pre- and postsynaptic activity during chronic desipramine treatment. Eur J Pharmacol 68: 41-47.

Invernizzi RW, Garattini S (2004). Role of presynaptic alpha2adrenoceptors in antidepressant action: recent findings from microdialysis studies. Prog Neuropsychopharmacol Biol Psychiatr 28: 819-827.

Isbister GK, Bowe SJ, Dawson A, Whyte IM (2004). Relative toxicity of selective serotonin reuptake inhibitors (SSRIs) in overdose. J Toxicol Clin Toxicol 42: 277-285.

Jobe PC, Dailey JW, Wernicke JF (1999). A noradrenergic and serotonergic hypothesis of the linkage between epilepsy and affective disorders. Crit Rev Neurobiol 13: 317-356.

Johnson EK, Jones JE, Seidenberg M, Hermann BP (2004). The relative impact of anxiety, depression, and clinical seizure features on health-related quality of life in epilepsy. Epilepsia 45: 544-550.

Kanner AM, Balabanov A (2002). Depression and epilepsy: how closely related are they? Neurology 58(Suppl 5): S27-S39.

Kanner AM, Kozak AM, Frey M (2000). The use of sertraline in patients with epilepsy: is it safe? Epilepsy Behav 1: 100-105.

Kanner AM, Nieto JC (1999). Depressive disorders in epilepsy. Neurology 53(Suppl 2): S26-S32.

Kaye CM, Haddock RE, Langley PF, Mellows G, Tasker TC, Zussman BD et al (1989). A review of the metabolism and pharmacokinetics of paroxetine in man. Acta Psychiatr Scand 350(Suppl): 60-75.

Krahl SE, Clark KB, Smith DC, Browning RA (1998). Locus coeruleus lesions suppress the seizure-attenuating effects of vagus nerve stimulation. Epilepsia 39: 709-714.

Krahl SE, Senanayake SS, Pekary AE, Sattin A (2004). Vagus nerve stimulation (VNS) is effective in a rat model of antidepressant action. J Psychiatr Res 38: 237-240.

Lee KC, Finley PR, Alldredge BK (2003). Risk of seizures associated with psychotropic medications: emphasis on new drugs and new findings. Expert Opin Drug Saf 2: 233-247.

Lemberger L, Bergstrom RF, Wolen RL, Farid NA, Enas GG, Aronoff GR (1985). Fluoxetine: clinical pharmacology and physiologic disposition. J Clin Psychiatr 46: 14-19.

McIntyre DC, Edson N, Chao G, Knowles V (1982). Differential effect of acute $v s$ chronic desmethylimipramine on the rate of amygdala kindling in rats. Exp Neurol 78: 158-166.

Murphy P, Likhodii S, Nylen K, Burnham WM (2004). The antidepressant properties of the ketogenic diet. Biol Psychiatr 56: 981-983.

Nestler EJ, McMahon A, Sabban EL, Tallman JF, Duman RS (1990). Chronic antidepressant administration decreases the expression of tyrosine hydroxylase in the rat locus coeruleus. Proc Natl Acad Sci USA 87: 7522-7526.

Parini S, Renoldi G, Battaglia A, Invernizzi RW (2005). Chronic reboxetine desensitizes terminal but not somatodendritic alpha(2)-adrenoceptors controlling noradrenaline release in the rat dorsal hippocampus. Neuropsychopharmacololgy print copy in press (originally published online Jan. 19, 2005 at www.acnp.org/citations/Npp1300661 ).

Peterson SL, Trzeciakowski JP, St Mary JS (1985). Chronic but not acute treatment with antidepressants enhances the electroconvulsive seizure response in rats. Neuropharmacology 24: 941-946.

Pisani F, Oteri G, Costa C, Di Raimondo G, Di Perri R (2002). Effects of psychotropic drugs on seizure threshold. Drug Saf 25: 91-110.

Pisani F, Spina E, Oteri G (1999). Antidepressant drugs and seizure susceptibility: from in vitro data to clinical practice. Epilepsia 40(Suppl 10): S48-S56. 
Raju SS, Noor AR, Gurthu S, Giriyappanavar CR, Acharya SB, Low HC et al (1999). Effect of fluoxetine on maximal electroshock seizures in mice: acute vs chronic administration. Pharmacol Res 39: 451-454.

Ressler KJ, Nemeroff CB (1999). Role of norepinephrine in the pathophysiology and treatment of mood disorders. Biol Psychiatr 46: 1219-1233.

Richmond R, Zwar N (2003). Review of bupropion for smoking cessation. Drug Alcohol Rev 22: 203-220.

Sanacora G, Mason GF, Krystal JH (2000). Impairment of GABAergic transmission in depression: new insights from neuroimaging studies. Crit Rev Neurobiol 14: 23-45.

Schachter SC (2004). Vagus nerve stimulation: mood and cognitive effects. Epilepsy Behav 5(Suppl 1): S56-S59.

Schank JR, Liles LC, Weinshenker D (2005). Norepinephrine is required for the full anticonvulsant effects of valproic acid in mice. Epilepsy Res (in press).

Suzdak PD, Gianutsos G (1985). Parallel changes in the sensitivity of gamma-aminobutyric acid and noradrenergic receptors following chronic administration of antidepressant and GABAergic drugs. A possible role in affective disorders. Neuropharmacology 24: 217-222.

Szot P, Weinshenker D, Rho JM, Storey TW, Schwartzkroin PA (2001). Norepinephrine is required for the anticonvulsant effect of the ketogenic diet. Brain Res Dev Brain Res 129: 211-214.

Szot P, Weinshenker D, White SS, Robbins CA, Rust NC, Schwartzkroin PA et al (1999). Norepinephrine-deficient mice have increased susceptibility to seizure-inducing stimuli. J Neurosci 19: 10985-10992.

Thomas SA, Marck BT, Palmiter RD, Matsumoto AM (1998). Restoration of norepinephrine and reversal of phenotypes in mice lacking dopamine beta-hydroxylase. J Neurochem 70: 2468 2476.

Thomas SA, Matsumoto AM, Palmiter RD (1995). Noradrenaline is essential for mouse fetal development. Nature 374: 643-646.

Thomas SA, Palmiter RD (1997). Impaired maternal behavior in mice lacking norepinephrine and epinephrine. Cell 91: 583-592.
Weinshenker D, Szot P (2002). The role of catecholamines in seizure susceptibility: new results using genetically engineered mice. Pharmacol Ther 94: 213-233.

Weinshenker D, Szot P, Miller NS, Palmiter RD (2001). Alpha(1) and beta(2) adrenoreceptor agonists inhibit pentylenetetrazoleinduced seizures in mice lacking norepinephrine. J Pharmacol Exp Ther 298: 1042-1048.

Weinshenker D, White SS, Javors MA, Palmiter RD, Szot P (2002). Regulation of norepinephrine transporter abundance by catecholamines and desipramine in vivo. Brain Res $\mathbf{9 4 6}$ 239-246.

White CM, Gailey RA, Levin GM, Smith T (1997). Seizure resulting from a venlafaxine overdose. Ann Pharmacother 31: $178-180$.

Wiegartz P, Seidenberg M, Woodard A, Gidal B, Hermann B (1999). Co-morbid psychiatric disorder in chronic epilepsy: recognition and etiology of depression. Neurology 53(Suppl 2): S3-S8.

Wong EH, Sonders MS, Amara SG, Tinholt PM, Piercey MF, Hoffmann WP et al (2000). Reboxetine: a pharmacologically potent, selective, and specific norepinephrine reuptake inhibitor. Biol Psychiatr 47: 818-829.

Xu F, Gainetdinov RR, Wetsel WC, Jones SR, Bohn LM, Miller GW et al (2000). Mice lacking the norepinephrine transporter are supersensitive to psychostimulants. Nat Neurosci 3: 465-471.

Yan QS, Dailey JW, Steenbergen JL, Jobe PC (1998). Anticonvulsant effect of enhancement of noradrenergic transmission in the superior colliculus in genetically epilepsy-prone rats (GEPRs): a microinjection study. Brain Res 780: 199-209.

Yan QS, Jobe PC, Dailey JW (1993). Noradrenergic mechanisms for the anticonvulsant effects of desipramine and yohimbine in genetically epilepsy-prone rats: studies with microdialysis. Brain Res 610: 24-31.

Zienowicz M, Wislowska A, Lehner M, Taracha E, Skorzewska A, Maciejak P et al (2005). The effect of fluoxetine in a model of chemically induced seizures-behavioral and immunocytochemical study. Neurosci Lett 373: 226-231. 